\title{
Captive breeding of peregrine and other falcons in Great Britain and implications for conservation of wild populations
}

\author{
L. Vincent Fleming ${ }^{1, *}$, Andrew F. Douse ${ }^{2}$, Nick P. Williams ${ }^{3}$ \\ ${ }^{1}$ Joint Nature Conservation Committee, Monkstone House, City Road, Peterborough PE1 1JY, UK \\ ${ }^{2}$ Scottish Natural Heritage, Great Glen House, Leachkin Road, Inverness IV3 8NW, UK \\ ${ }^{3}$ Animal Health, Clyst House, Winslade Park, Clyst St Mary, Exeter EX5 1DY, UK
}

\begin{abstract}
Numbers of captive-bred peregrine falcons Falco peregrinus and other species of falcon, which are subject to compulsory registration in Britain, increased substantially over the period from 1983 to 2008, such that $>7800$ were registered in captivity in 2007. Much of this increase has been due to the international demand for, and consequent production of, novel hybrids for international trade. Over the same period, the wild peregrine population recovered from pesticide-induced decline and expanded its range into lowland Britain. Wild and captive peregrine 'populations' are linked through the taking into captivity of wild birds and through the escape of captive birds. Such escapes occur in numbers ( $>1500$ over the study period from 1983 to 2007) that are potentially capable of enabling recruitment to the wild; escaped birds are predominantly hybrid and peregrine falcons, and the latter may be of mixed or uncertain provenance. Escaped peregrines are under-recorded by birdwatchers compared with non-native falcons. The benefits and risks for wild peregrine populations of the captive breeding of falcons are considered, especially with respect to any potential human-induced genetic introgression from escaped falcons.
\end{abstract}

KEY WORDS: Captive breeding $\cdot$ Peregrine falcon - Falco peregrinus $\cdot$ Genetic introgression · Hybrid falcons · International trade - Escapes · CITES

\section{INTRODUCTION}

The role of captive breeding in conservation has typically been considered in the context of its contribution to the recovery of wild populations or the maintenance of ex situ populations (e.g. Rahbek 1993). Captive production and breeding of wildlife for primarily commercial purposes (www.cites.org/ eng/res/05/05-10R15.shtml) or for personal use has rarely been subject to similar scrutiny. However, whether such captive production has an impact on wild populations of the same species is subject to a range of opposing views (see www.cites.org/ eng/cop/14/doc/E14-48.pdf). On the one hand, some claim that captive production can reduce the demand in trade for wild-taken specimens by providing an alternative, legitimate source of supply and so may undermine or displace illegal trade. In doing so, such captive production can contribute significantly to the conservation of wild populations (IUCN SSC unpubl.; see also www.cites.org/eng/cop/14/doc/E14-48.pdf). On the other hand, some claim that such captive production may have unintended negative consequences, such as potentially reducing incentives to conserve wild populations, shifting the benefits of wildlife trade from developing to developed countries, providing a cover under which to 'launder' into trade illegally taken wild specimens and, by stimu- 
lating but not meeting demand, place greater pressure on wild populations (IUCN SSC unpublished, also see www.cites.org/eng/cop/14/doc/E14-48.pdf). However, there are relatively few well-documented case studies to enable the relative merits of these arguments to be examined (IUCN SSC unpubl.). MacGregor (2006) provided an example of the implications of the captive production and breeding of crocodilians for incentives to conserve wild populations; Haitao et al. (2008) considered the potential impacts of large-scale commercial captive production of turtles in China. For crocodilians, Hutton \& Webb (2003) concluded that legal trade, including that derived from captive production, could displace illegal trade.

There is a significant trade in, and demand for, birds of prey, especially falcons Falco spp., for the sport of falconry and for captive collections. As a result, all Falco spp. have been listed in Appendices I and II of the Convention on International Trade in Endangered Species of Wild Fauna and Flora (CITES) since its ratification in 1975. Accordingly, international trade in these species is regulated by a series of import and export permits. In brief, species in Appendix II may be traded internationally if such trade is not detrimental to their survival in the wild. By contrast, commercial international trade is prohibited in the more threatened species listed in Appendix I unless such specimens are captive bred, in which case they are treated as if they are Appendix II specimens. Some of the species traditionally most valued in falconry, namely peregrine falcon $F$. peregrinus and gyrfalcon $F$. rusticolus, are listed in Appendix I. Techniques for captive breeding of peregrine and other falcons were originally developed in North America, and to a lesser extent in Europe, in the 1960s and 1970s and focused on the peregrine falcon, firstly because of its desirability for falconry and, secondly, to provide birds to re-populate, through re-introduction, some declining or extirpated peregrine populations (Cade \& Temple 1977). As a result of CITES provisions, which provide a de facto incentive for captive breeding of Appendix I species valued in trade, and a related series of legislative measures at the national level to protect wild populations of these falcons, there has been a major shift in Europe, including Britain, away from the use of wild-taken specimens for falconry and a corresponding shift towards the increased use of captivebred falcons (Kenward \& Gage 2009, Kenward 2009).

Great Britain (GB) provides a useful case study to assess any impacts on the conservation of wild falcons of this move to captive breeding and to consider the conditions under which trade in captive-bred specimens may be beneficial for wild populations (Sutherland et al. 2009). Britain has a long and continuing tradition of falconry (Ratcliffe 1993, Kenward 2009). It also has significant populations of wild falcons, especially of peregrine falcons, which are now in recovery following earlier pesticide-induced declines and which are subject to regular population monitoring (Ratcliffe 1993, Greenwood et al. 2003). Significantly, from 1983 to 2007, legislation in Britain required a number of bird taxa, including falcons and their hybrids, if kept in captivity to be ringed and registered with a government department as a measure to deter the illegal take of wild birds (Williams \& Evans 2000); subsequently, following a review (Defra 2006), the number of species for which registration is required has been substantially reduced (e.g. www. legislation.gov.uk/uksi/2008/2356/made). There is thus a $25 \mathrm{yr}$ period of documented changes in the numbers and species composition of most falcons kept in captivity which also spans a period when the licensed removal of falcons from the wild in GB ceased.

In this study we aim to: (1) describe trends in the numbers, origin and taxonomic composition of peregrine and other falcons in captivity from 1983 to 2007; (2) analyse the factors affecting such changes; and (3) assess any risks and benefits of captive breeding for wild peregrine populations. We focus particularly on the peregrine falcon because it is the only falcon breeding in the wild in Britain which is also listed in Appendix I of CITES; it is desirable in falconry; it has been the focus of considerable conservation attention; and it has special protection under British legislation (Ratcliffe 2003).

\section{METHODS}

\section{Trends in numbers and taxonomic composition of falcons in captivity}

Information on captive birds of prey held before 1983, when the requirement for registration began, is derived from Kenward (1979), who estimated the number and origin of such birds held in 1975 and 1978. Subsequently, the provisions of the 1981 Wildlife \& Countryside Act (WCA) required any bird listed in its Schedule 4 to be ringed and registered if kept in captivity (Williams \& Evans 2000). This legislation applies only to GB (namely England, Scotland and Wales) and not to the United Kingdom (UK) as a whole (thus the legislation does not apply to north- 
Table 1. Falco spp. Falcon species listed in Schedule 4 of the Wildlife \& Countryside Act (WCA) from 1983 to 2007

\begin{tabular}{|ll|}
\hline Common name & Scientific name \\
\hline Barbary falcon $^{\text {Gyrfalcon }}{ }^{\mathrm{a}}$ & Falco pelegrinoides \\
Hobby $^{\mathrm{a}}$ & F. rusticolus \\
Lesser kestrel & F. subbuteo \\
Mauritius kestrel $_{\text {Merlin }}^{\mathrm{a}}$ & F. naumanni \\
Peregrine & F. punctatus \\
${ }^{\text {a Species receiving additional protection under }}$ \\
Schedule 1 of the WCA & F. columbarius \\
\hline
\end{tabular}

ern Ireland). All such registrations are now with the Animal Health agency (formerly with predecessor bodies) which also supplies the rings or cable-ties, each uniquely numbered, to be fitted to the birds; compliance is encouraged through a series of inspections (Williams \& Evans 2000). Failure to register any bird listed in Schedule 4 constitutes a criminal offence.

In 1981, the Schedule listed all birds in the family Falconidae. Subsequently, a review in 1993 removed from the Schedule all falcons apart from the 7 species listed in Table 1. Unless stated otherwise, all references to captive falcons in this paper refer to these 7 listed species and not to species formerly included in the Schedule. All hybrids of the listed species (Table 1) also had to be registered during the study period (1983 to 2007), whether they were hybrids between falcons listed in Schedule 4 or between a Schedule 4 species and a non-listed species. Data for peregrine falcons, hybrid falcons and 'other' falcons (namely all species in Table 1 other than hybrids and the peregrine falcon) are presented separately in the present study. Nomenclature follows that used in the WCA and CITES, the latter being based on Dickinson (2003).

All bird registrations are entered into an electronic database with details of the species, ring number, location where kept, keeper, date of registration (and when registration ceases), and, if known, hatch date, parental details, origin (wild, wild-disabled, captive bred, imported and unknown) and ultimate fate (dead, transferred to another keeper, exported, lost, released or unknown). Details are recorded in the database as they are provided by the keeper and are not routinely subject to any secondary checks. Electronic data entry only began on 20 March 1986; all birds registered before, and still alive on, this date will thus appear as if registered in 1986. The database is owned and managed by Animal Health and is not publicly available. The dataset, supplied by Animal Health, on which most of the analyses in this paper are based, was downloaded on 26 February 2008. Archived data on the species removed from the Schedule in 1993 remain available.

The database does not enable certain retrospective analyses to be undertaken (e.g. to query how many specimens of a particular species were registered on a certain date in the past). However, it has been the practice by Animal Health and its predecessors (from 1989) to collate, on a specific date towards the end of each calendar year, an annual census of all birds registered. This census was taken on 15 November each year except in 1999, 2000 and 2002 (when taken on 1 January), 2001 (15 September), 2003 (15 January) and 2004 (17 January). No census data are available for 1998. Census data are presented by the calendar year in which they were taken (see Fig. 1). Records for the number of young produced each year (with the exception of 1989) were also recorded by Animal Health and its predecessor bodies: for peregrine from 1987 to 2007 and for other falcons from 1989 to 2007. Data for hybrids in such annual censuses were only distinguished from data for full species beginning in 1994.

\section{Factors affecting trends in captive falcons}

The UK has been a Party to CITES since it came into force in 1975. There are thus full data on all regulated imports and exports of Falco spp. into or out of the UK and, indeed, from any other country Party to CITES. These data are accessible from the United Nations Environment Programme - World Conservation Monitoring Centre (UNEP-WCMC) CITES Trade Database (www.unep-wcmc.org/citestrade/trade.cfm); UNEP-WCMC (2004) provides guidance on the interpretation of such data. It is not possible from CITES trade data to distinguish between trade in birds derived from the component parts of the UK (in particular between Britain and Northern Ireland).

Within the European Community (EC), CITES has been implemented since 1984 through regulations that apply in all member states (Morgan 2003). These regulations were amended in 1997 (EC Regulation 338/97) following, amongst other things, the abolition of internal border controls within the EC (Morgan 2003). As a result, from 1997, data are no longer available for 'imports' and 'exports' between other EC member states; moreover, the number of member states has increased over the same period. However, these later EC CITES regulations required that all 
commercial use of species listed on their Annex A (including all Falco spp.) be regulated by the issue of certificates. As a result, there is good information from 1997 onwards on internal trade in, and other commercial use of, falcons within the UK. These data are stored on a licensing database known as Unicorn, managed by Animal Health and its predecessors (and not publicly available), to which we had access.

Estimates of the prices charged for falcons in trade in the UK were obtained by examining advertisements in the weekly national periodical 'Cage \& Aviary Birds' (IPC Media, London) over the period from 1 September 2005 to 30 March 2006; care was taken to avoid repeated advertisements being counted more than once. These figures were then compared with an earlier exercise (The Royal Society for the Protection of Birds unpubl.) when advertised prices had been recorded from the same periodical over a period of 8 yr (1981 to 1987 inclusive). In order to correct figures for monetary inflation, the retail price index (www. crowsnest.co.uk/north/rpi.htm) for the median month of each study period was used to adjust the 2005/2006 figures to 1984/1985 prices.

Origin of founder stock. The use of peregrine nestlings taken from the wild for falconry or aviculture (including captive breeding) in GB was permitted under licence until 1988; thereafter, no licences for such wild use were issued (Fox \& Chick 2007). Numbers of birds legally removed from the wild in this way between 1971 and 1978 were reported by Kenward (1979) and, subsequently, were derived from UK reports on derogations from the EC Birds Directive (1979/EEC/409) and correspondence, where available, taken from archived internal files, between the relevant government departments and the Nature Conservancy Council, the statutory adviser on nature conservation at the time. Imported falcons also contributed to the taxonomic composition and increase of falcons in captivity (Kenward 1979; UNEP-WCMC CITES trade database) as did some injured wild birds which may, by law, only be retained in captivity if they are so disabled as to prevent their return to the wild (referred to as 'wild-disabled'). Data for 204 wild and wild-disabled birds, all registered before 2000 but whose date of first registration had been corrupted to 1 January 2000, were excluded from some analyses. The bird registration scheme does not routinely record the nature of any disabilities affecting wild-disabled birds, but such data are available, from 1997, for applications for the commercial use of such birds.

\section{Risks and benefits to wild populations}

Size of wild populations. Breeding peregrines in both GB and the UK as a whole have been subject to full national censuses at intervals of ca.10 yr since 1971 (Ratcliffe 1972, 1985, Crick \& Ratcliffe 1995, Banks et al. 2010). Between these censuses, wild populations are less intensively monitored by voluntary fieldworkers in raptor study groups (e.g. Etheridge et al. 2007).

Evidence of illegal take or trade. Peregrine and other falcon species are listed in Schedule 1 of the WCA (Table 1), which gives them special protection under law, making it an offence, amongst other things, to take, possess or to sell, offer or possess birds for the purposes of sale. Information on any illegal activity is, by its nature, difficult to obtain. However, information was taken from literature and other sources where available.

Numbers of falcons released or escaping to the wild. Numbers of captive birds lost to the wild (typically when being flown for falconry), and which had not been recovered, were recorded in the registration database. These data exclude birds which temporarily escape or are at hack in the wild for falconry purposes and which are subsequently re-captured. The deliberate release to the wild of peregrine falcons of wild or wild-disabled origin was analysed separately from that of birds of captive-bred origin.

In addition, in order to assess how many escaped falcons were observed by birdwatchers, a sample of annual county, regional or country bird reports was consulted (see Table S1 in the supplement, available online at www.int-res.com/articles/suppl/n014p243_ supp.pdf). Although the number of bird reports available for each year was not constant (ranging from 8 to 15), they represent 322 'report years' from 1981 to 2006, account for a significant geographical coverage of GB and are likely to indicate the relative abundance of escaped falcons observed by birdwatchers. We did not attempt to determine whether observations represented repeat sightings of the same bird nor did we attempt to correct for 1 bird being recorded in more than 1 report unless such interpretation was suggested in the report itself. Thus, sightings are more likely to be over-estimates of birds seen than under-estimates. Evidence for birds being presumed to have escaped from captivity is typically because the birds still have falconers' jesses attached (the majority of records for peregrine falcons), because the birds appear to be hybrids, or because they are non-native species whose occurrence in a genuine wild state is deemed unlikely, or a combina- 
tion of these factors. As gyrfalcons can occur in a genuine wild state in Britain, only those records which indicated a captive origin of such birds were collated.

Statistical analysis. Descriptive statistics were undertaken using Microsoft Excel. Regression analyses were undertaken using SPSS version 13 software (under licence). The dependent data in such analyses were in percentages; following tests to determine the normality of such data, these data were not transformed.

Definitions. Definitions of captive breeding vary between CITES and the WCA, being less strict in the latter. A bird recorded in the registration database as captive bred might thus conceivably be considered captive bred by the WCA but not by CITES; in practice this is likely to refer to only a small number of birds.

\section{RESULTS}

\section{Trends in numbers, origin and taxonomic composition of falcons in captivity}

Trends in the numbers of captive falcons (Table 1), derived from bird registration, in GB are illustrated in Fig. 1a. In all, since registration commenced in 1983 (to 26 February 2008), some 8051 peregrines, 4273 other falcons and 11778 hybrid falcons have been registered as being in captivity. The overwhelming majority of these birds are recorded as being captive bred (21902 or $91 \%$ of all falcons; 6918 or $86 \%$ of peregrines). On 15 November 2007, 7824 falcons were registered as being in captivity, comprising 2457 peregrines, 1231 other falcons and 4136 hybrids. This represents a significant increase from the 99 falcons which Kenward (1979) estimated were possessed by falconers in 1978, of which only some $3 \%$ were peregrine or Barbary falcons Falco pelegrinoides. Several species commonly kept by falconers, such as saker $F$. cherrug and lanner $F$. biarmicus falcons, and for which registration is not required (see Table 1), are not included in these totals.

Artificial insemination has enabled a wide range of hybrids to be produced between virtually any Falco species. At least 12 falcon species in a wide variety of combinations are represented in the lineage of the hybrids bred in captivity in GB. Based on birds registered in November 2007, most registered hybrids (95\%, 3921 birds) were a combination of 2 species (in varying proportions), a smaller number $(5 \%, 210$ birds) had 3 species in their lineage, and a very small number $(0.1 \%, 5$ birds) had 4 species. Of hybrids reg-

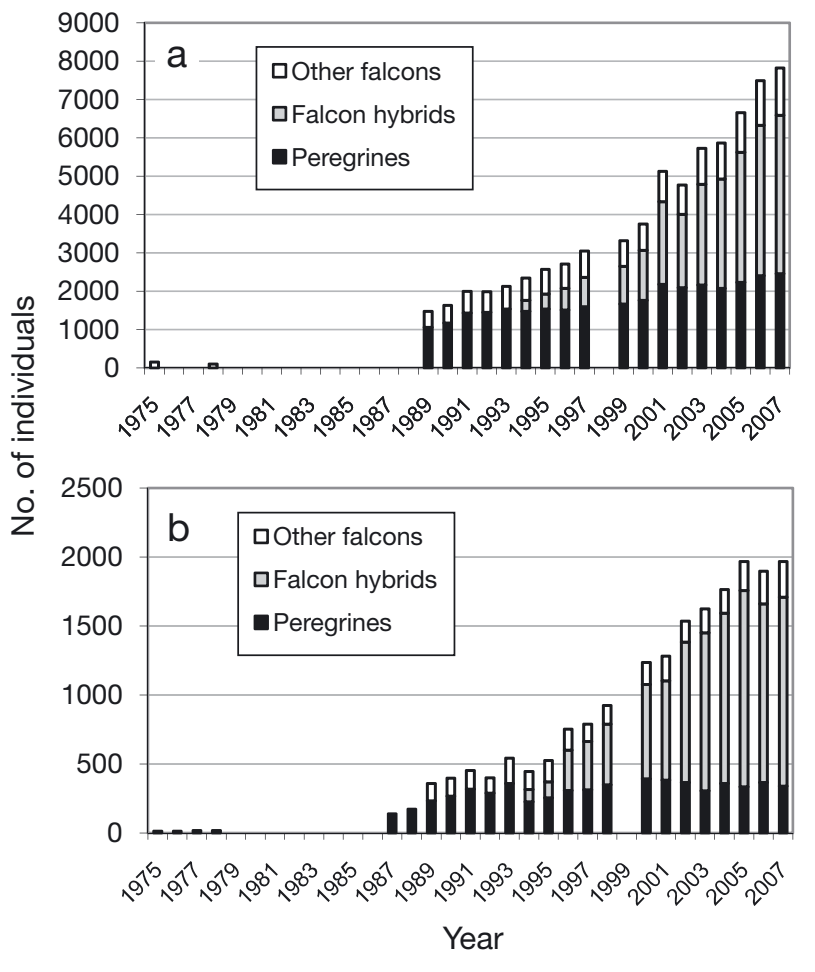

Fig. 1. Falco spp. Numbers of peregrine, hybrid and other falcons (a) registered as being in captivity on a sample census date in each of the years from 1989 to 2007 (no census data are available for 1998) and (b) recorded annually as being bred in captivity in each of the years from 1987 to 2007 (no data for 1999; data for peregrines available from 1987, for other falcons from 1989). Data for hybrid falcons were only distinguished from full species from 1994 onwards. Note that data for the years 1975 and 1978 are derived from Kenward (1979) and refer to all falcons except for common kestrel $F$. tinnunculus

istered in November 2007, the most abundant hybrid combination was between gyr and saker falcons (44\%, 1843 birds), followed by peregrine and gyrfalcon hybrids $(16 \%, 679$ birds), peregrine and saker falcon hybrids $(12 \%, 521$ birds), and hybrids of these 3 species combined $(3 \%, 133$ birds). In all, hybrids of these 3 species, in their various combinations, accounted for $77 \%$ of all hybrids.

Although data for hybrid falcons were not distinguished from pure species until 1994, hybrid falcons have been largely responsible for the striking increase in numbers of captive falcons overall (Fig. 1a). Hybrid falcons registered on annual census dates did not outnumber peregrine falcons until 2003 (and did not outnumber peregrine and all other full falcon species combined until 2005). However, when the numbers of birds bred annually are compared (Fig. 1b), production of hybrids exceeded numbers of peregrines bred from 1997 onwards and all other 
species combined by 2000. For example, in 1994, peregrines accounted for $50 \%$ of the total number of falcons bred in captivity ( 226 of 447 birds) and hybrid falcons for just $20 \%$ (89 birds). By contrast, in 2007, peregrines accounted for only $17 \%$ of all young produced (340 of 1969 birds) and hybrids for 70\% (1371 birds); the production of peregrines appears to have reached a plateau with a mean of $341 \pm 23.3$ (SD) birds produced annually over the 5 most recent years indicating constant, if limited, demand.

Origin of founder stock. The founders of peregrines bred in captivity in Britain are derived from imported birds and wild-taken British birds. From 1971 to 1978, Kenward (1979) recorded 804 falcons (of all species except common kestrel Falco tinnunculus) as imported into the UK, a mean of $100 \pm 47.1$ (SD) per year. Over the same period, he estimated the recruitment of 49 native falcons (mean: $6 \pm 4.1$ per year) wild-taken under licence supplemented with, from 1973 onwards, 85 (mean: $10 \pm 8.2$ birds per year) captive-bred birds. In other words, imported birds constituted the majority ( $86 \%$ ) of birds estimated to have been obtained by falconers between 1971 and 1978. CITES trade data are available from 1975 onwards. Over the period 1975 to 1978 where CITES data overlap with those reported by Kenward (1979), gross imports to the UK of all falcons reported to CITES totalled 98 birds ( $24 \pm 16.6$ per annum), suggesting lower levels of imports than those estimated by Kenward (1979), viz. a mean of $64 \pm 30.1$ per annum over the same period. CITES gross import data themselves are likely to over-estimate actual imports (UNEP-WCMC 2004). Of the CITESrecorded imports of falcons for 1975 to 1978, only 18 were peregrine falcons, of which $13(72 \%)$ were of the sub-species F. peregrinus brookei and F. $p$. calidus, neither of which is native to the UK.

Imports of peregrines to the UK reported to CITES peaked in the early 1980s and again in the early 1990s (Fig. S1, available in the supplement at www.int-res.com/articles/suppl/n014p243_supp.pdf). Most CITES imports are not recorded to sub-species level, but of 398 peregrines imported to the UK in 1976 to 2005 inclusive, 63 (15\%) were non-native sub-species. The majority of these $(51 \%)$ were Falco peregrinus pealei but, in addition to the sub-species recorded above, also included F. p. anatum and F. $p$. peregrinator. It is likely that a greater proportion of imports than these figures suggest were of nonnative sub-species; a further 88 peregrines $(22 \%$ of all imports) were imported from countries, notably the United States and Canada, where captive-bred birds were more likely to be sub-species other than

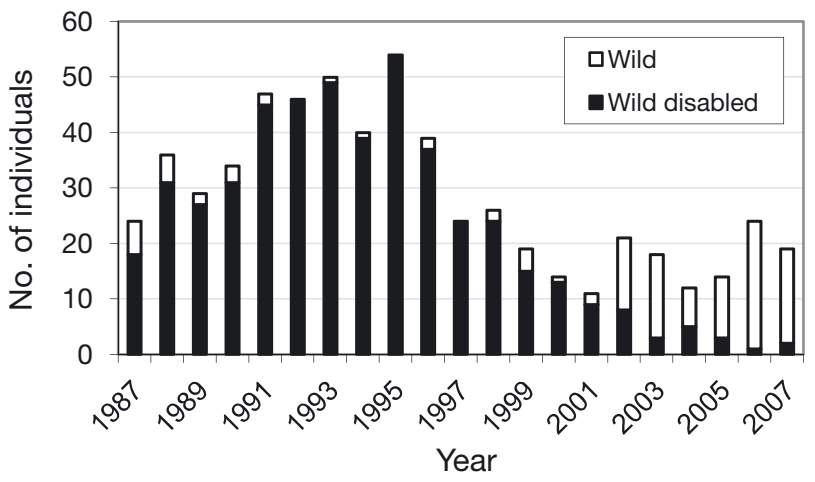

Fig. 2. Falco peregrinus. Numbers of peregrine falcons of 'wild' and 'wild-disabled' origin registered in captivity by the year in which they were first registered (note that these data exclude birds for which no first date of registration is recorded and birds whose registration date had been corrupted; see 'Methods' for explanation)

the nominate sub-species native to Britain. Early imports of non-native peregrines, as founder stock for captive breeding, are likely to have made a proportionately greater contribution to the genetic composition of the captive progeny than those imported later when numbers had increased. Relatively few falcon hybrids (91) have been imported.

Recruitment of wild birds to captivity. From 1985 to 2007 , some 646 wild-disabled and 159 peregrines of wild origin were registered in captivity, a total of 805 birds (Fig. 2). Of these, 178 (22\%) were recorded as subsequently lost or released (Table 2). The proportion of each category lost or released to the wild is similar between wild-disabled birds $(21 \%)$ and birds of wild origin $(26 \%)$, suggesting that the distinction between these categories is not being applied consistently, that the definitions are not clear to keepers or that some birds make a greater recovery from injuries than anticipated. Nevertheless, 627 birds, comprising 117 wild and 510 of wild-disabled origin, were retained in captivity. In order to assess how many of these may have bred, we took, as a sample, all the birds of wild (36) or wild-disabled (107) origin

Table 2. Falco peregrinus. Total number of peregrines registered in captivity of wild origin or of wild-disabled origin and percentages (in parentheses) recorded as released to the wild or as lost/escaped birds; data from 1987 to 2007 inclusive

\begin{tabular}{|lccc|}
\hline & Wild-disabled & Wild & Total \\
\hline Lost & $55(8.5)$ & $12(7.5)$ & $77(9.5)$ \\
Released & $81(12.5)$ & $30(18.9)$ & $111(13.7)$ \\
Total lost/released & $136(21.0)$ & $42(26.4)$ & $178(22.1)$ \\
Total registered & 646 & 159 & 805 \\
\hline
\end{tabular}


registered in captivity on 15 November 2005 and then examined how many of these were subsequently recorded as parents in the database. Of this sample of wild and wild-disabled birds, 4 birds of wild origin $(11 \%)$ and 25 of wild-disabled origin (23\%) had bred; extrapolating these proportions to all 627 retained birds suggests that 13 birds of wild origin and 117 of wilddisabled origin could have bred in captivity, equivalent to $21 \%$ of all retained birds.

Data on licensed use from 1978 onwards are incomplete but suggest that some 32 peregrines were legally removed from the wild for the purposes of falconry and/or aviculture over the period from 1985 to 1988 inclusive. This is a rate broadly consistent with that reported by Kenward (1979) for the years 1971 to 1978. This licensed use probably accounts for the numbers of wildorigin birds first registered in the late 1980s. Even so, birds of wild-disabled origin significantly outnumber these, and the numbers of peregrines registered in this category continued to rise to a peak in the mid1990s (Fig. 2). Thereafter, numbers of wild and wilddisabled peregrines registered in captivity declined, although in recent years, more birds have been recorded as being of wild origin than of wild-disabled origin. The reason for this trend is not clear, especially as the number of peregrines in the wild was increasing over this period (and so more disabled birds were likely). The greater availability and affordability of captive-bred birds may have reduced the incentive for keepers to retain and tend disabled birds.

In a sample of 145 applications for the commercial use of wild-origin peregrines made between 1997 and 2004 inclusive, no record of any disability is recorded for 67 birds (46\%), and a further 14 (9\%) were birds confiscated by law enforcement authorities. Of the remainder, 57 (39\%) had physical injuries and disabilities, and 13 (9\% of applications, 19\% of recorded disabilities) were recorded as being malimprinted upon humans, thus preventing their release.

\section{Factors affecting trends in captive falcons}

Value of captive falcons. The advertised values of captive-bred falcons, when adjusted for inflation, diminished considerably from the 1980s to 2005/2006 for all species for which there are comparable data (Table 3). Whilst retail price indices are commonly used to adjust figures for inflation, their use here should be interpreted with caution. The indices are based on the prices of a range of commonly available household goods which do not include commodities such as live falcons. Nevertheless, they provide the only readily available means of comparing prices between different periods of time. For some species, too few figures were available in 1 of the 2 periods to determine a mean price; accordingly, we also included data on saker and lanner falcons (for which registration was not required after 1993) as commonly available captive-bred falcons. Gyrfalcons are advertised at much higher prices than other captive falcons.

Trade in captive falcons. Falcons captive bred in the UK are in demand elsewhere in the world, and a proportion of such birds are exported annually (Fig. S2 at www.int-res.com/articles/suppl/n014p243_supp. pdf). UK trade reports do not enable exports of full species to be distinguished from hybrids and so, for analysis of UK exports of captive falcons, these data are derived from reports made solely by importing countries. Typically such reports more accurately record actual trade, but as some countries which are the recipients of exported birds may only have joined CITES in recent years, they will not have reported any imports of birds before they acceded to the Convention. Some importing countries may also have formal 'reservations' on some listings, where they opt out of applying the provisions of CITES with respect to the species concerned, and so may not fully report trade. Accordingly, these data should be treated with some caution. These data also exclude exports of 
peregrine and other falcons to other member states of the EC before 1997 which, typically, were not reported by the importer.

Whilst there has been a continuing low volume of reported international trade from the UK in peregrine falcons (typically far fewer than 100 specimens $\mathrm{yr}^{-1}$ ) suggesting a regular but limited demand, recent years have seen a substantial increase in trade in hybrid and other falcons, matching the growth of production of hybrids recorded in Fig. 1b. In all, from 1975 to 2005, 2355 hybrid falcons produced in the UK are recorded as imports by non-EU countries, with the majority recorded in trade to the United Arab Emirates (75\%), Qatar (14\%) and Kuwait (9\%); $97 \%$ of all imports of UK-produced hybrid falcons have been reported from, and including, the year 2000 (but Qatar and Kuwait only acceded to CITES in 2001 and 2002, respectively). Trade in other falcons produced in the UK has also grown in recent years, and this trade is dominated by gyrfalcons, with 300 individual birds reported as being imported from the UK during the period 1995 to 2005 inclusive.

If CITES-reported imports by other countries of UK-bred peregrine and hybrid falcons are expressed as a percentage of the birds bred in that year (Fig. S3 at www.int-res.com/articles/supp/n014p243_supp. pdf), there is an exponential increase in the proportion of hybrid falcons being exported annually $(y=$ $0.1015 \mathrm{e}^{0.3469 \mathrm{x}} ; \mathrm{r}^{2}=0.9561 ; \mathrm{n}=9, \mathrm{p}=0.001$, based on analysis of untransformed data with $x$-axis values converted to Year 1 in 1987, Year 2 in 1988 and so on). Less than $10 \%$ of such hybrid birds were exported in 2000 compared with, in 2005, 51\% (724 birds) of the 1423 birds reported as bred in captivity that year (Fig. S3). It is possible that this proportion will not be exceeded, as the larger female birds are most in demand in the export trade, with the smaller males retained for the domestic market (International Hybrid Committee 1999). By contrast, the apparent increase in the proportion of peregrines exported is not significant $(y=0.7544 x-0.0936 ; n=18, p>0.1)$.

\section{Risks and benefits to wild populations}

Size of the wild population. The size of the UK peregrine population has been subject to a national census approximately every 10 yr since 1962 (Ratcliffe 1963, 1972, 1984, Crick \& Ratcliffe 1995, Banks et al. 2010). Following the pesticide-induced nadir in the 1960s, the number of territories occupied by peregrines has recovered, such that in 2002 it stood at 1426 pairs, representing $163 \%$ of the 1930 s baseline of 874 pairs (Banks et al. 2010).

Estimates of illegal nest interference and take. Information gathered during the course of the national censuses provided estimates of illegal take of eggs or nestlings and other incidents of nest interference (Table 4). As the presentation of data in the various censuses does not enable direct comparisons between the proportion of known clutches removed or destroyed (Table 4), nest interference is expressed here as a proportion of all breeding opportunities (or known pairs). The data suggest apparent low levels of known nest interference in 1961/1962 and 1971 (ca. $2 \%$ of breeding opportunities), a proportional and absolute rise in known nest interference in 1981 and 1991 (5 to $6 \%$ ), with a subsequent fall in 2002 (to $1 \%$ ). These data exclude cases of nest interference which were only suspected and whose inclusion

Table 4. Falco peregrinus. Increase in the UK wild peregrine population and estimates of nest interference involving eggs and chicks as derived from decadal censuses since 1961. Occupied territories are considered 'breeding opportunities'. Estimates of known nest interference exclude cases recorded as 'suspected' only. Known nest interference is shown as a \% of breeding opportunities. GB: Great Britain

\begin{tabular}{|c|c|c|c|c|c|}
\hline Year & $\begin{array}{l}\text { Occupied } \\
\text { territories }\end{array}$ & $\begin{array}{l}\text { No. of } \\
\text { clutches/broods }\end{array}$ & $\begin{array}{l}\text { Estimate of known nest } \\
\text { interference }\end{array}$ & $\begin{array}{l}\text { Known nest } \\
\text { interference }(\%)\end{array}$ & Source \\
\hline $1961 \& 1962$ & $\begin{array}{l}356 \\
\text { (GB only) }\end{array}$ & & $\begin{array}{l}\text { Young taken from } 9 \text { nests in each of } \\
1961 \text { (legally) and } 1962 \text { (illegally) }\end{array}$ & 2 & Ratcliffe (1963) \\
\hline 1971 & $\begin{array}{l}341 \\
\text { (GB only) }\end{array}$ & $\begin{array}{l}157 \text { broods } \\
\text { hatched }\end{array}$ & Young taken from 6 nests & 2 & Ratcliffe (1972) \\
\hline 1981 & 768 & 531 clutches & $\begin{array}{l}\text { Nests robbed of } 29 \text { clutches \& } 18 \\
\text { broods }\end{array}$ & 6 & Ratcliffe (1984) \\
\hline 1991 & 1283 & 912 clutches & $\begin{array}{l}\text { Nests robbed of } 45 \text { clutches \& } 21 \\
\text { broods }\end{array}$ & 5 & $\begin{array}{l}\text { Crick \& Ratcliffe } \\
\text { (1995) }\end{array}$ \\
\hline 2002 & 1426 & & $\begin{array}{l}13 \text { incidents of 'persecution' of eggs } \\
\text { or young }\end{array}$ & 1 & Banks et al. (2010) \\
\hline
\end{tabular}


would increase these percentages. Records of nest robberies and destruction provide an estimate of human interference but must be treated with caution because it is not clear if records of nest interference were analysed consistently between censuses and because it is not always possible to determine with certainty the motive behind any nest interference, the ultimate fate of any specimens illegally removed from nests or whether nest contents were simply removed or destroyed by those wishing to protect game stocks or racing pigeons. In the 1971 census, Ratcliffe (1972) considered that illegal taking of young for falconry was then the commonest cause of breeding failure once the young had hatched; he also noted that in the period of the 1981 census, eggs were also being taken to hatch and rear young in captivity (Ratcliffe 1984). Mearns \& Newton (1988) reported that human robberies of eggs and young, recorded from a more intensive study of peregrines in southern Scotland from 1974 to 1982, accounted for $6 \%$ and $3 \%$ of all breeding opportunities, respectively. Locally, rates of nest interference may have been higher still, with peaks in the early 1990s (Horne \& Fielding 2002).

The use of DNA profiling to determine familial relationships amongst captive raptors enables claims of captive breeding to be tested (Shorrock 1998). A sample of birds $(<60$ peregrines; G. Shorrock pers. comm.) tested in 1993 and 1994 in targeted investigations found that 39 peregrine falcons declared as captive bred were not related to their claimed parents, amounting to some $11 \%$ of the 360 peregrines and their hybrids registered as having been bred in captivity in 1993 (Shorrock 1998). These tests resulted in successful prosecutions and custodial sentences. Subsequently, further DNA testing during announced inspections in 1995 and 1996 of 35 peregrine falcons found no discrepancies with claimed familial relationships (Williams \& Evans 2000). In 1994 , between these 2 sampling periods, the number of peregrine falcons (and their hybrids) recorded as having been produced in captivity fell by more than $20 \%$ (Williams \& Evans 2000; Fig. 1b).

Loss of captive birds to the wild. In total, the registration database records the loss to the wild of 1564 individual falcons during the study period. The majority of these (687 ind.; $44 \%$ of total) were peregrine falcons, followed closely by hybrid falcons (642 ind.; $41 \%)$. The remainder comprise other falcon species (235 ind.; 15\%), of which merlins comprised the majority $(77 \%)$ of that category (182 ind.; $12 \%$ of all escapes). These figures exclude birds of wild or wilddisabled origin.

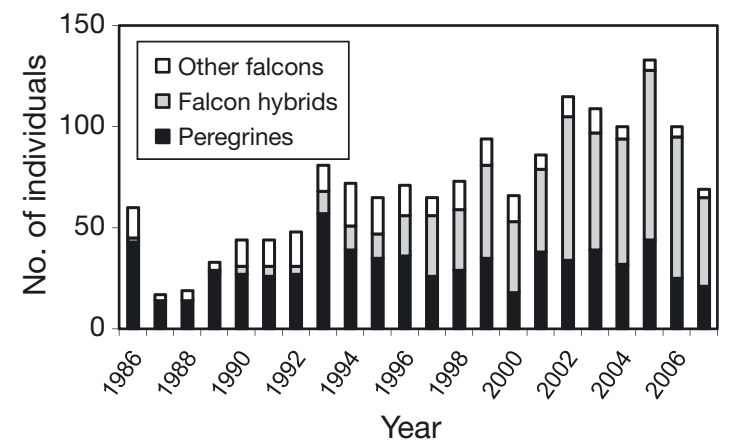

Fig. 3. Falco spp. Number of registered falcons recorded as having been 'lost' from captivity in Great Britain from 1983 to 2007 (note that data for 1986 include all losses from 1983 to 1986 inclusive). Data exclude wild and wild-disabled birds reported as lost or released

Peregrines accounted for the majority of all escapes, with a peak of 57 birds in 1993 (Fig. 3), until 1997 when losses of hybrid falcons first exceeded those of peregrine. Since then the proportion of hybrid falcons has steadily increased such that by 2006 they accounted for $71 \%$ of all losses to the wild.

Excluding combined data from 1983 to 1986, losses of peregrine falcons from captivity to the wild have, on average, been broadly similar over the 2 decades (1987 to 1997 and 1998 to 2007 covered by registration with means of $30 \pm 7.3$ and $31 \pm 5.1$ (95\% confidence limits, $\mathrm{p}=0.05$ ) birds $\mathrm{yr}^{-1}$ lost to the wild in each decade, respectively. By contrast, losses of hybrid falcons have increased 6 -fold between the 2 decades, from a mean of $9 \pm 3.9$ ind. $\mathrm{yr}^{-1}$ to $54 \pm$ 13.1 ind. $\mathrm{yr}^{-1}$. There is no legal obligation for keepers to report lost or escaped birds, so these figures can safely be considered as underestimates.

From 2005, there is an indication of a reduction in the number of birds, in all categories, being lost to the wild (Fig. 3). When the number of birds reported as lost in a year is expressed as a percentage of the number of birds recorded as registered on the census date in the same year (data only available from 1989 to 2007; Fig. 4), there is a clear indication of a reduction over time in the proportion of birds being lost from captivity to the wild. These results should be treated as being indicative only — birds are lost in a series of chance events throughout the year, whilst the numbers of birds registered are derived from a single but variable census date in each year. Nevertheless, this decline in the proportion of birds being lost each year is statistically significant when subject to simple regression analysis on untransformed data (with $x$-axis values converted to Year 1 in 1987, Year 2 in 1988 and so on) as follows: peregrine $(y=-0.078 x+2.874 ; \mathrm{n}=18 ; \mathrm{p}<0.01)$, hybrid falcons 


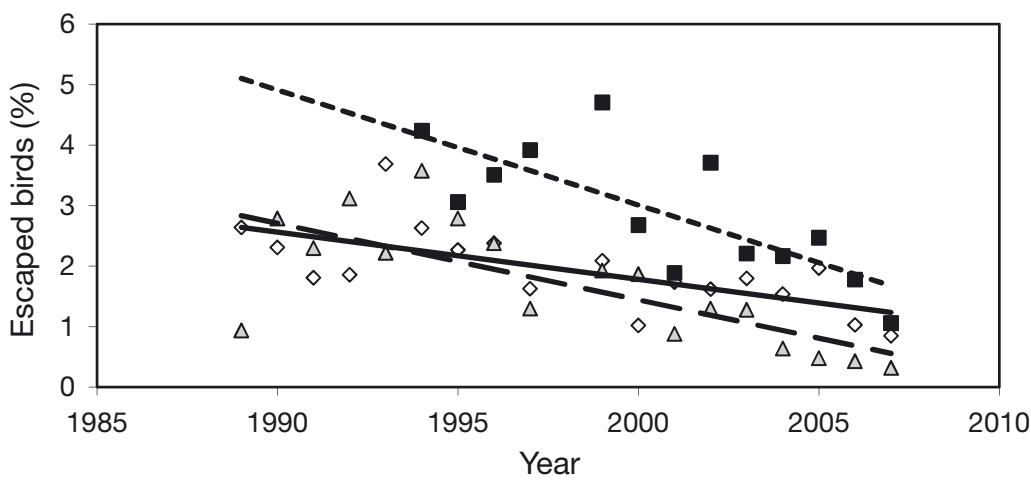

Fig. 4. Falco spp. Number of peregrine $\left(\diamond\right.$; solid line), hybrid ( $\mathbf{q}_{\text {; }}$ dotted line) and other falcons $(\Delta$; dashed line) reported annually as 'lost' (i.e. escaped to the wild) as a percentage of the total number registered in captivity on a census date in each year (see Fig. 1). No data available for 1998; data exclude wild and wild-disabled birds reported as lost or released less likely to report birds thought to have escaped from captivity (Marchant 1996), and it was clear from our collation that the number of bird reports recording non-native escaped birds increased over time. Equally, peregrine sightings may have been subject to greater scrutiny in counties where they are, or were, naturally scarce.

Archived bird registration data are available for escaped saker and lanner falcons from 1986 to 1994 inclusive, which, when combined with data on escaped peregrines, enable comparison of escaped birds with those reported in the wild by birdwatchers. Over this period, 275 peregrines, 200 lanner falcons and 84 saker falcons were recorded as lost to the wild, a ratio of 3.3 peregrines and 2.3 lanners to every escaped saker. In the bird reports analysed for this period, 12 peregrines ( $4 \%$ of reported escaped birds) were recorded along with 21 lanner falcons $(10 \%$ of escapes) and 18 saker falcons ( $21 \%$ of escapes), a ratio of 0.7 peregrines and 1.2 lanners to every saker with, overall, $9 \%$ of birds being seen post escape. From this sample, escaped peregrines are evidently under-recorded by birdwatchers relative to the number of escaped birds. This is not surprising when the only means most observers will have to distinguish escaped peregrines from native wild individuals is by the presence or absence of jesses, bells or other falconry furniture. By contrast, other falcons, such as sakers, will be conspicuously different from native birds and are likely to attract attention from birdwatchers.

were not subject to bird registration after 1993 (and thus we have no recent data on number of escapes), but we report these species here because they constitute the majority of escaped falcons reported by birdwatchers. Many unidentified escaped falcons were reported as 'saker-type' or 'lannertype'. Indeed, whilst hybrid falcons begin to be reported from the 1990s and rise to a peak in 2004, 'other falcons' were routinely reported in greater numbers (Fig. 5). It is likely that many birds identified as lanner or saker falcons may have been hybrids (and perhaps vice versa) given the difficulties of discriminating between species and their hybrids (Eastham \& Nicholls 2005) especially when observed in the wild. These results need to be treated with some caution. Some bird watchers may be

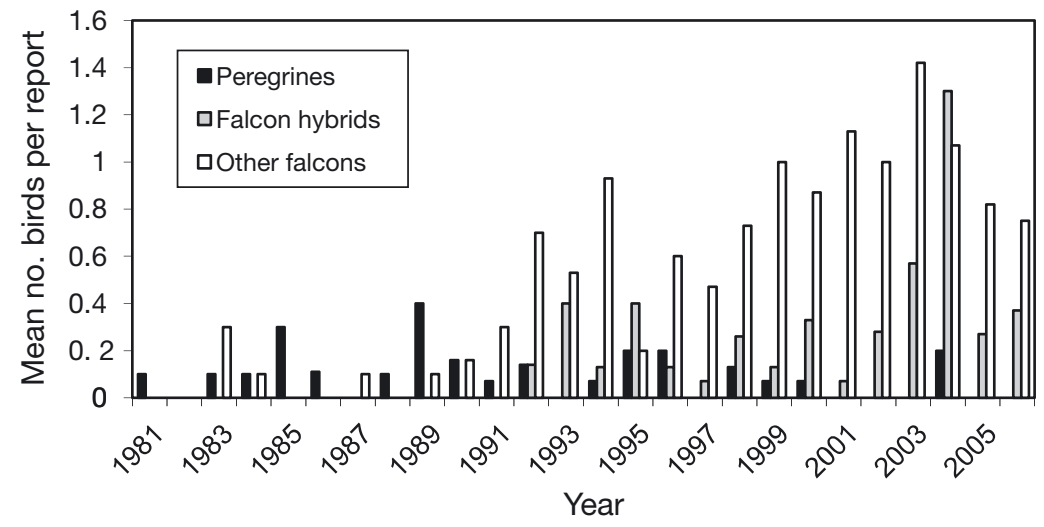

Fig. 5. Falco spp. Mean number of escaped peregrines, hybrid or unidentified falcons (as 'hybrids' in key), and other falcons reported annually in a sample of regional bird reports from 1981 to 2005; note that in this instance 'other falcons' includes sightings of saker and lanner falcons 
It is also clear from the various bird reports that some escaped hybrid and non-native falcons are capable of surviving in the wild for extended periods, with some birds being reported persistently over 1 or more years. The Devon Bird Report records attempted breeding by a saker falcon in 1992 when, having displaced a pair of breeding peregrines, an escaped female laid a clutch of 3, presumably infertile, eggs. This bird was recorded at the site in a third year. We are also aware of other occasions where escaped falcons have interfered with breeding peregrines and where peregrines, having the appearance of non-native sub-species of peregrine falcon, have been observed breeding in the wild (N.P. Williams pers. obs.).

\section{DISCUSSION}

This paper records the significant increase in the captive breeding of peregrine and other falcons in Britain from 1983 to 2007. This increase mirrors that for other CITES-listed species which are in demand in trade. For example, $72 \%$ of all the crocodilian specimens recorded in trade in 1999 were of captivebred origin (MacGregor 2006), and $95 \%$ or more of orchids in trade are artificially propagated (www. cites.org/eng/cop/12/prop/E12-P51.pdf).

The probable factors driving this increase in captive breeding of falcons include the ongoing market demand for falcons in Britain and overseas, the limitations on the availability of specimens from the wild and the development of improved captive breeding techniques. Moreover, for species listed in Appendix I of CITES, such as the peregrine, commercial trade is only permitted in captive-bred and not wild specimens, thus providing a significant incentive for captive breeding. Indeed, the incipient increase in captive breeding of peregrines in Britain provided the justification, under EC Directives, for regulatory authorities to suspend licensed removal from the wild of birds (because captive breeding provided a satisfactory alternative to such wild use). The increase in captive breeding supported a comparable increase in the number of falconers in Britain (Kenward 2009). A substantial shift towards the production, through artificial insemination, of novel falcon hybrids has also occurred. Such hybrids have attributes which make them more desirable to falconers than pure-bred birds - they may be larger and faster than pure-bred specimens, be less prone to disease, be more desirable aesthetically and may outperform wild-caught or pure-bred falcons (International Hybrid Committee 1999, Kenward 2009). Indeed, the production of such hybrids now greatly exceeds that of pure-bred specimens and is strongly linked to the demand for them in international trade, especially in the Middle East where their use has been promoted as a means of reducing unsustainable use of wildtaken saker falcons (www.cites.org/eng/com/AC/20/ E20-08-1.pdf). A similar pattern has emerged for orchids where the trade is also dominated by the artificial propagation of hybrids (www.cites.org/eng/ cop/12/prop/E12-P51.pdf).

Over the same period in which the numbers in captivity have increased, peregrines breeding in the wild in the UK have also undergone a period of population recovery and expansion, such that they now considerably exceed the 1930s baseline (Banks et al. 2010). The increase in the wild population has been driven by controls on the use of organochlorine pesticides, increased legal protection and a reduction in deliberate illegal killing and nest interference (Ratcliffe 2003). However, within this overall population increase there have been declines in some regions (typically in north and west Britain) but also a significant range expansion into lowland Britain using man-made structures as novel breeding sites (Banks et al. 2010).

Although these 2 'populations', wild and captive, appear to have increased independently of one another, our results show that there is a continuing interchange between them. On the one hand, wild birds are routinely taken into captivity, while on the other hand, captive birds escape to the wild in significant numbers. In the continuing absence of licensed removal of peregrines from the wild for falconry or aviculture, the majority of wild birds known to be taken into captivity have been predominantly disabled birds (Fig. 2). With up to $21 \%$ of these wildorigin birds breeding in captivity, combined with previous imports of, presumably unrelated, birds from outside the UK and EC (Fig. S1), it seems that there should be little risk of inbreeding in the current captive 'population' overall.

Birds in captivity may also originate from illegal take, but the extent of this is difficult to assess. It is evident from DNA testing (Shorrock 1998, Williams \& Evans 2000) and estimates of nest interference from census data that illegal taking of wild birds into captivity has occurred, perhaps especially before 1993. This risk had been effectively mitigated by a combination of regulation (compulsory bird registration), more effective enforcement techniques (targeted inspections and DNA testing) and market responses (greater availability of falcons and hybrids at lower prices), all deterring or reducing the incen- 
tive for the illegal take of birds from the wild. Indeed, the production of hybrids may, initially, have been stimulated, amongst other things, by the desire of some breeders to avoid allegations of illegal take (Shorrock 1998, Fox \& Chick 2007, Kenward 2009, Kenward \& Gage 2009).

However, whilst wild birds have found their way variously into captivity, an unintended consequence of the increase in numbers of captive falcons has been an associated rise in their number escaping to the wild. What is the likelihood of such escaped birds surviving, and subsequently breeding, in the wild?

Unlike planned re-introductions, the escape of captive falcons, as a series of chance events, is likely to be dispersed spatially and temporally, thus reducing the chances of birds of non-native species or provenance establishing breeding populations. Wildreared birds are more likely to survive and recruit to wild populations than captive-bred falcons (Brown et al. 2006) especially as escape from captivity is more akin to a 'hard release' than to the 'soft release' favoured in deliberate re-introductions. Fox \& Chick (2007) estimated that most escaped falconers' birds would die within days. Yet Holroyd \& Banasch (1990) found that 6 to $10 \%$ of (soft) released captive-bred peregrines were re-sighted after $1 \mathrm{yr}$. Kenward et al. (1981) found that $40 \%$ of falconry-trained goshawks Accipiter gentilis survived after simulated loss to the wild. However, there is clearly likely to be a difference in probable survival after escape between falconry-trained birds experienced at hunting and inexperienced or untrained birds.

Nevertheless, for peregrines (687 escaped birds) and hybrid falcons (642), these escapes occur at levels which exceed or approach those known to be capable of establishing populations of peregrines in the wild through planned re-introductions (e.g. Holroyd \& Banasch 1990, Tordoff \& Redig 2001, Jacobsen et al. 2007). Equally, the escape or deliberate release from captivity of other raptors is implicated in the establishment in Britain of breeding populations of goshawk (Marquiss 1981, Marquiss \& Newton 1982) and eagle owl Bubo bubo (Melling et al. 2008). Evidence from county bird reports and Everitt \& Franklin (2009) also demonstrates that some escaped birds are capable of surviving in the wild for prolonged periods (in some cases years) after their escape and have attempted to breed, even if rarely.

What are the consequences to wild populations of escaped birds? On the debit side, such escaped birds may compete with wild birds for mates, food and/or nest sites. There is also a risk, first recognised in the 1970s (Beyerbach 1977) and more recently reiterated by Birdlife International (2008), that hybrid birds may pair with wild birds and introduce alien genes into the population (Eastham \& Nicholls 2005). Birdlife International (2008) called for the production of hybrid falcons to be banned in the $\mathrm{EC}$ to reduce the risk from such introgression to native falcon populations, especially of the globally threatened saker falcon. The risks to wild populations from human-induced introgression with nonnative species (Simberloff 1996) or domestic forms of the same or closely related species are well recognised for other native species such as polecat Mustela putorius (Davison et al. 1999) and wildcat Felis sylvestris (Beaumont et al. 2001, Kitchener et al. 2005). Measures to address such risks have included a programme to eradicate ruddy duck Oxyura jamaicensis from the UK, to protect whiteheaded duck O. leucocephala in Spain from the threat of hybridisation (Hughes et al. 2006), and to suspend the release of captive-bred lesser whitefronted geese Anser erythropus in Scandinavia, due to concerns about the genetic integrity of the captive stock (Jones et al. 2008). Whilst there is 1 reported example in Britain of a hybrid falcon pairing and producing young with a wild peregrine (Everitt \& Franklin 2009), others are reported from Europe and North America (Tordoff \& Redig 1997, Lindberg \& Nesje 2002, Birdlife International 2008, Kleinstäuber et al. 2009) and more may go undetected; falcon hybrids, especially juveniles, are not always readily distinguishable from their parent species (Eastham \& Nicholls 2005, Birdlife International 2008). This risk may also apply in regions to which hybrid falcons are exported (Birdlife International 2008). Yet Kenward (2009) considered that selection pressures operate against the survival of intermediate phenotypes and that the occasional escape of hybrids would not threaten healthy falcon populations; although escapes in Britain are regular, not occasional, numbers of escaped hybrids are small relative to the size of the wild peregrine population. Any risk of hybrids breeding in the wild is likely to be diminished further by the reduced fertility of some hybrids, especially of female birds (Eastham \& Nicholls 2005). Despite falconers' birds escaping to the wild for many years, no non-native falcon species has yet become established in the UK.

Anthropogenic-induced genetic introgression is not only a risk posed by hybrid birds; many of the peregrines bred in captivity may be sub-species (derived from imports) other than Falco peregrinus peregrinus of native provenance or they may have a 
complex lineage comprising different sub-species and provenances. Escaped captive-bred peregrines breeding in the wild are even less likely to be detected than hybrids, such escaped peregrines being significantly under-recorded by birdwatchers compared with other escaped falcons. Different subspecies and genotypes of captive-bred peregrines, released as part of recovery programmes, are known to persist in the wild in proportions which do not differ significantly from those of released birds (Tordoff \& Redig 2001) and which are sufficient to alter the genetic composition of the wild population (Jacobsen et al. 2007).

On the credit side, such escapes of peregrines may arguably have contributed, albeit inadvertently, to the current recovery of peregrines in Britain and may even have provided some unintentional compensation for birds, broods and clutches lost to illegal human persecution and nest interference. Ratcliffe (2003) suggested that multiple factors may be involved in the recent range expansion of peregrines into lowland, inland Britain and their increased elasticity of choice of breeding site, especially in their use of man-made structures. Whilst this shift in range and nest site choice has coincided with an overall increase in the peregrine population (Banks et al. 2010), and so presumably increasing competition for nest sites, it has also coincided with the regular escape to the wild of captive-bred birds. We suggest a complementary hypothesis that may explain, in part, this shift to novel structures in lowland Britain, namely that recruitment of escaped captive-bred peregrines to the wild may have contributed to this plasticity of nest site choice. Whilst we have no direct evidence to support this hypothesis, such escaped birds will have been raised in artificial structures, may be habituated to people (and so be more tolerant of urban environments) and will not have any natal fidelity to the traditional range of peregrines. Whilst sporadic nesting on buildings in Britain has previously been recorded (Ratcliffe 1993), most man-made structures in lowland Britain were not used for breeding by peregrines. Any escaped captive-bred birds which survived sufficiently long in the wild may have been able to initiate breeding on such novel sites, free of competition from established wild birds. Captive-bred peregrines released in the United States most often returned to the kind of site from which they were released (Holroyd \& Banasch 1990); nest site selection was strongly influenced by the type of site (cliffs versus man-made structures) from which birds fledged (Kleinstäuber et al. 2009), especially for males (Tordoff et al. 1998). Re-intro- duced captive-bred peregrines are, in some areas, now predominantly birds of urban areas (Tordoff \& Redig 2001).

The recent reduction in the proportion of captive birds escaping to the wild (Figs. $3 \& 4$ ) may be linked to the adoption by falconers of a policy statement and code of practice on flying hybrid and non-native falcons (Fox \& Chick 2007), to the greater use and availability of radio telemetry equipment and to a disproportionate increase in keepers of captive falcons for breeding and display purposes rather than for practising falconry. Regardless, as the impact of escaped falcons on wild populations is not known, we strongly recommend that evidence be sought for any humaninduced genetic introgression into native peregrine populations arising from escaped captive-bred falcons and that the fate, survival and recruitment to the wild of such escaped birds be studied to enable any risks, or indeed any benefits, to be evaluated and quantified.

Taking all these factors into account, is it possible to assess the risks and benefits of the growth in captive production of peregrine and other falcons? It is clear that captive breeding of falcons has been successful in its role of providing a legitimate and reliable supply of birds for falconry and as an alternative to taking birds from the wild. Demand for falcons in Europe could not now be met from sustainable wild harvests (Kenward 2009), and export of captive-bred birds, especially hybrids, to parts of the Middle East has reduced there the demand for, and unsustainable harvests of, wild-taken birds, especially saker falcons (www.cites.org/eng/com/AC/20/E20-08-1.pdf). The techniques developed for captive breeding could and have been applied to the conservation and recovery of other raptors, although it is not clear what proportion, if any, of the captive falcon gene pool in Britain has been managed to maximise any future contribution to conservation needs. Risks of illegal take have been mitigated by regulation (although now amended; www.legislation.gov.uk/uksi/2008/2356/ made), enforcement (using DNA analysis) and the greater affordability of captive-bred birds; the extent of any human-induced genetic introgression into wild populations arising from escaped captive-bred falcons remains to be evaluated.

Acknowledgements. We thank M. Bose and J. Hounslow of Animal Health for enabling access to the bird registration datasets and providing advice on their interpretation. We are very grateful for helpful comments on a draft manuscript from A. Dixon, R. E. Kenward, M. Marquiss, D. McNiven, D. Morgan, G. Shorrock and C. Wernham. V.F. thanks his col- 
leagues of the Joint Nature Conservation Committee (JNCC) for their assistance and comments. We thank 3 anonymous referees for their helpful comments on this paper. The views expressed here do not necessarily reflect those of the JNCC, Scottish Natural Heritage or Animal Health.

\section{LITERATURE CITED}

Banks AN, Crick HQP, Coombes R, Benn S, Ratcliffe DA, Humphries EM (2010) The breeding status of peregrine falcons Falco peregrinus in the UK and Isle of Man in 2002. Bird Study 57:421-436

Beaumont M, Barratt EM, Gottelli D, Kitchener AC, Daniels MJ, Pritchard JK, Bruford MW (2001) Genetic diversity and introgression in the Scottish wildcat. Mol Ecol 10: 319-336

Beyerbach U (1977) Hybridisation and introduction of alien birds. In: Cooper JE, Kenward RE (eds) Papers on the veterinary medicine and domestic breeding of diurnal birds of prey. British Falconers Club, Oxford, p 62-63

Birdlife International (2008) Minimising threats from hybrid falcons (originating from captive-bred birds) on wild European falcon populations. Birdlife International, Cambridge. Available at www.birdlife.org/eu/pdfs/ Nature_Directives_material/BHDTF_Position_Hybrid_ Falcons-2008_04_23.pdf (accessed 25 June 2009)

> Brown JL, Collopy MW, Gott EJ, Juergens PW, Montoya AB, Hunt WG (2006) Wild-reared aplomado falcons survive and recruit at higher rates than hacked falcons in a common environment. Biol Conserv 131:453-458

Cade TJ, Temple SA (1977) The Cornell University falcon programme. In: Chancellor RD (ed) World Conference on Birds of Prey. Report of Proceedings. Vienna 1975. International Council for Bird Preservation, Hampshire, p 353-369

Crick HQP, Ratcliffe DA (1995) The peregrine Falco peregrinus breeding population of the United Kingdom in 1991. Bird Study 42:1-19

Davison A, Birks JDS, Griffiths HI, Kitchener AC, Biggins D, Butlin RK (1999) Hybridization and the phylogenetic relationship between polecats and domestic ferrets in Britain. Biol Conserv 87:155-161

Defra (Department of Environment, Food and Rural Affairs) (2006) Review of registration under section 7 of the Wildlife and Countryside Act 1981 in England, Scotland and Wales. Consultation document. Department of Environment, Food and Rural Affairs, London

Dickinson EC (2003) The Howard \& Moore complete checklist of the birds of the world. 3rd edn. Christopher Helm, London

Eastham CP, Nicholls MK (2005) Morphometric analysis of large Falco species and their hybrids with implications for conservation. J Raptor Res 39:386-393

Etheridge B, Holling M, Riley H, Wernham C, Thompson D (2007) Scottish raptor monitoring scheme. Report 2005. Scottish Ornithologists' Club, Aberlady

Everitt PJ, Franklin J (2009) First UK record of a wild freeliving peregrine falcon female breeding and producing young with a hybrid male falcon of domestic origin. In: Sielicki J, Mizera T (eds) Peregrine falcon populations status and perspectives in the 21st century. Turul, Warsaw, p 585-592

Fox NC, Chick J (2007) Falconry in the United Kingdom: an audit of the current position prepared by the Hawk
Board. Hawk Board Publications. Available at www. hawkboard-cff.org.uk/uk_falconry_audit.pdf (accessed 30 June 2008)

Greenwood JJD, Crick HQP, Bainbridge IP (2003) Numbers and international importance of raptors and owls in Britain and Ireland. In: Thompson DBA, Redpath SM, Fielding AH, Marquiss M, Galbraith CA (eds) Birds of prey in a changing environment. The Stationery Office, Edinburgh, p 25-49

> Haitao S, Parham JF, Zhiyong F, Meiling H, Feng Y (2008) Evidence for the massive scale of turtle farming in China. Oryx 42:147-150

Holroyd GL, Banasch U (1990) The reintroduction of the peregrine falcon Falco peregrinus anatum into southern Canada. Can Field Nat 104:203-208

Horne G, Fielding AH (2002) Recovery of the peregrine falcon Falco peregrinus in Cumbria, UK, 1966-99. Bird Study 49:229-236

Hughes B, Henderson I, Robertson P (2006) Conservation of the globally threatened white-headed duck, Oxyura leucocephala, in the face of hybridization with the North American ruddy duck, Oxyura jamaicensis: results of a control trial. Acta Zool Sin 52(Suppl):576-578

Hutton J, Webb G (2003) Crocodiles: legal trade snaps back. In: Oldfield $S$ (ed) The trade in wildlife: regulation for conservation. Earthscan, London, p 108-120

International Hybrid Committee (1999) The scale of production and use of hybrid falcons in captivity. Falco 13:13-14

Jacobsen F, Nesje M, Bachmann L, Lifjeld JT (2007) Significant genetic admixture after re-introduction of peregrine falcon (Falco peregrinus) in southern Scandinavia. Conserv Genet 9:581-591

Jones T, Martin K, Barov B, Nagy S (comps) (2008) International single species action plan for the conservation of the western palearctic population of the lesser whitefronted goose Anser erythropus. AEWA Tech Ser No. 36. Bonn. Available at www.unep-aewa.org/activities/ working_groups/lwfg/lwfg_ssap_130109.pdf (accessed 4 August 2010)

Kenward RE (1974) Mortality and fate of trained birds of prey. J Wildl Manag 38:751-756

Kenward R (1979) The numbers of birds of prey obtained and possessed by falconers in the United Kingdom. Falconer 7:158-163

Kenward RE (2009) Conservation values from falconry. In: Dickson B, Hutton J, Adams B (eds) Recreational hunting, conservation and rural livelihoods. Wiley-Blackwell, Chichester, p 181-196

Kenward RE, Gage MJG (2009) Opportunities in falconry for conservation through sustainable use. In: Sielicki J, Mizera T (eds) Peregrine falcon populations - status and perspectives in the 21st century. Turul, Warsaw, p 181-204

Kenward RE, Marquiss M, Newton I (1981) What happens to goshawks trained for falconry? J Wildl Manag 45: 802-806

Kitchener AC, Yamaguchi N, Ward JM, Macdonald DW (2005) A diagnosis for the Scottish wildcat (Felis sylvestris): a tool for conservation action for a criticallyendangered felid. Anim Conserv 8:223-237

Kleinstäuber G, Kirmse W, Sömmer P (2009) The return of the peregrine to eastern Germany - re-colonisation in the west and east: the formation of an isolated tree-nesting subpopulation and further management. In: Sielicki J, Mizera T (eds) Peregrine falcon populations - status 
and perspectives in the 21st century. Turul, Warsaw, p 641-676

Lindberg P, Nesje M (2002) Lost falconers birds and hybrid falcons - Do they have an impact on European peregrine falcon (Falco peregrinus) populations? - A case study of lost falconers birds breeding in Sweden. In: Yosef $\mathrm{R}$, Miller ML, Pepler D (eds) Raptors in the new millennium - world conference on birds of prey \& owls, Raptor 2000. International Birding \& Research Center, Eilat, p 96

MacGregor J (2006) The call of the wild: captive crocodilian production and the shaping of conservation incentives. TRAFFIC International, Cambridge

Marchant JH (1996) Recording and monitoring of escaped and introduced birds in Britain and Ireland. In: Holmes JS, Simons JR (eds) The introduction and naturalisation of birds. HMSO, London, p 1-11

Marquiss M (1981) The goshawk in Britain - its provenance and current status. In: Kenward RE, Lindsay IM (eds) Understanding the goshawk. International Association for Falconry and Conservation of Birds of Prey, Oxford, p 43-57

Marquiss M, Newton I (1982) The goshawk in Britain. Br Birds 75:243-260

Mearns R, Newton I (1988) Factors affecting breeding success of peregrines in south Scotland. J Anim Ecol 57: 903-916

Melling T, Dudley S, Doherty P (2008) The eagle owl in Britain. Br Birds 101:478-490

Morgan D (2003) The European Community wildlife trade regulations. In: Oldfield $\mathrm{S}$ (ed) The trade in wildliferegulation for conservation. Earthscan, London, p 70-77

Rahbek C (1993) Captive breeding - a useful tool in the preservation of biodiversity? Biodiv Conserv 2:426-437

Ratcliffe DA (1963) The status of the peregrine in Great Britain. Bird Study 10:56-90

Editorial responsibility: Mike Bruford,

Cardiff, UK
Ratcliffe DA (1972) The peregrine population of Great Britain in 1971. Bird Study 19:117-156

Ratcliffe DA (1984) The peregrine breeding population of the United Kingdom in 1981. Bird Study 31:1-18

Ratcliffe DA (1993) The peregrine falcon. 2nd edn. Poyser, London

Ratcliffe DA (2003) The peregrine saga. In: Thompson DBA, Redpath SM, Fielding AH, Marquiss M, Galbraith CA (eds) Birds of prey in a changing environment. The Stationery Office, Edinburgh, p 91-98

Shorrock G (1998) The success of DNA profiling in wildlife law enforcement. Int J Biosci Law 1:327-341

Simberloff D (1996) Hybridization between native and introduced wildlife species: importance for conservation. Wildl Biol 2:143-150

Sutherland WJ, Adams WM, Aronson RB, Aveling R and others (2009) One hundred questions of importance to the conservation of global biological diversity. Conserv Biol 23:557-567

Tordoff HB, Redig PT (1997) Midwest peregrine falcon demography, 1982-1995. J Raptor Res 31:339-346

- Tordoff HB, Redig PT (2001) Role of genetic background in the success of reintroduced peregrine falcons. Conserv Biol 15:528-532

Tordoff HB, Martell MS, Redig PT (1998) Effect of fledge site on choice of nest site by Midwestern peregrine falcons. Loon 70:127-129

UNEP-WCMC (United Nations Environment Programme World Conservation Monitoring Centre) (2004) A guide to interpreting outputs from the CITES trade database. Version 6.0. September 2004. UNEP-WCMC, Cambridge

Williams NP, Evans JA (2000) The application of DNA technology to enforce raptor conservation legislation within Great Britain. In: Chancellor RD, Meyburg BU (eds) Raptors at risk. Proc 5th World Conf Birds Prey. World Working Group on Birds of Prey and Owls, Berlin, p 859-867

Submitted: April 14, 2010; Accepted: April 23, 2011 Proofs received from author(s): September 15, 2011 